\title{
Erratum to: Expression of messenger molecules and receptors in rat and human sphenopalatine ganglion indicating therapeutic targets
}

\author{
Anna Steinberg ${ }^{1,4^{*}}$, Simona D. Frederiksen ${ }^{2}$, Frank W. Blixt ${ }^{2}$, Karin Warfvinge ${ }^{2,3}$ and Lars Edvinsson ${ }^{2,3}$
}

Following the publication of the original article [1] it was brought to our attention that two minor errors were contained in the final article. Please see below for the sentences as they are now and how they should read upon revision:

Abstract, Results: We report that all three 5-HT receptors studied occur in neurons and satellite glial cells (SGCs) of the SPG.

This should read as:

We report that all three 5-HT receptors studied occur in neurons and nerve fibers of the SPG.

Discussion, first paragraph, line 6: Here we demonstrate that all three 5-HT receptor subtypes occur in neurons and SGCs of the rat SPG.

This should read as:

Here we demonstrate that all three 5-HT receptor subtypes occur in neurons and nerve fibers of the rat SPG.

\section{Author details}

'Karolinska Institutet, Department of Clinical Neuroscience, Division of Neurology, Karolinska University Hospital Solna, 17176 Stockholm, Sweden.

${ }^{2}$ Department of Clinical Sciences, Division of Experimental Vascular Research, Lund University, Lund, Sweden. ${ }^{3}$ Department of Clinical Experimental Research, Glostrup Hospital, University of Copenhagen, Glostrup, Denmark. ${ }^{4}$ Department of Neurology, Karolinska University Hospital Solna, S-171 76 Stockholm, Sweden.

Received: 9 September 2016 Accepted: 9 September 2016 Published online: 20 September 2016

\section{Reference \\ 1. Steinberg A et al (2016) Expression of messenger molecules and receptors in rat and human sphenopalatine ganglion indicating therapeutic targets. J Headache Pain 17:78}

\footnotetext{
* Correspondence: anna.steinberg@karolinska.se

${ }^{1}$ Karolinska Institutet, Department of Clinical Neuroscience, Division of Neurology, Karolinska University Hospital Solna, 17176 Stockholm, Sweden ${ }^{4}$ Department of Neurology, Karolinska University Hospital Solna, S-171 76 Stockholm, Sweden

Full list of author information is available at the end of the article
}

Submit your manuscript to a SpringerOpen ${ }^{\mathcal{O}}$ journal and benefit from:

- Convenient online submission

- Rigorous peer review

- Immediate publication on acceptance

- Open access: articles freely available online

- High visibility within the field

- Retaining the copyright to your article

Submit your next manuscript at $>$ springeropen.com
Springer Open

(C) 2016 The Author(s). Open Access This article is distributed under the terms of the Creative Commons Attribution 4.0 International License (http://creativecommons.org/licenses/by/4.0/), which permits unrestricted use, distribution, and reproduction in any medium, provided you give appropriate credit to the original author(s) and the source, provide a link to the Creative Commons license, and indicate if changes were made. 